\title{
Church and Religiousness of the Contemporary Czechs. Pedagogue's Reflections Based on the Polish Sources
}

Andrzej Ładyżyński / e-mail: aladyzynski@gmail.com Institute of Pedagogy, University of Wroclaw, Poland.

Ładyżyński, A. (2018). Church and Religiousness of the Contemporary Czechs. Pedagogue's Reflections Based on the Polish Sources. Czech-Polish Historical and Pedagogical Journal, 10/2, 38-47.

https://doi.org/10.5817/cphpj-2018-012

Church and religiousness in the Czech Republic are utterly fascinating matters. Czechs' historical experiences make them more distanced from the churches, especially the Catholic Church, hence working out differential attitudes to those of neighbouring countries. Two doctrines of Protestantism and Catholicism are heavily impacting each other in the Czech Republic. This, though, affects the attitudes of the Czech Republic citizens. Contemporary Czechs defy the institutional forms of religiousness. They recognize it as private and individual matters and the whole society is highly laicized.

Key words: church; religiousness; Czech Republic

\section{Introduction}

In some cultures, religion permeates every structure and aspect of social life, and in others, its role is limited and marginalized. Adopting a sociological perspective on religion, we may highlight the fact that it is expressed through the cultural patterns of social life, individual as well as in a group, which in Christian tradition are described as a category of Church. ${ }^{1}$ Church is an institutional structure and its existence itself has a social and cultural dimension. Since its dawn, Church has been a source of educational initiative creating schools, shaping social role models, and molding the society over the centuries. All these features apply to the Church role in the Czech Republic as it has been significant, but had a divergent function than Church had in other countries.

I think that the religious practices can be perceived as educational processes of acquiring the worshippers, shaping their beliefs and attitudes, implementing specific behaviours displayed through the religious dictates and prohibitions. "Religiousness is expressed through the man's attitude towards values, norms and

$1 \quad$ Świątkiewicz, W. (2001). Relikt przeszłości czy żywa codzienność? Refleksje wokół badań nad religijnością współczesną w krajach wyszehradzkich. In J. Budniak, A. Kasperek (Eds.), Oblicza religijności. Polska - Czechy - Słowacja, Katowice: PAN, Studio NOA, 29. 
symbols, which are experienced as religious ones by the group of individuals". ${ }^{2}$ It can be assumed that not only within the area of Czech Republic, but to a much broader extent, "there is a perspective of crisis described in the categories of secularization and laicization in the reflection upon the condition of contemporary religiousness (...)". ${ }^{3}$ These phenomena can be comprehended as a display of crisis as a change, but the trends of withdrawal from religiousness can also be attempted to be interpreted as an educational category. The essence of these concepts consists in making the society that is exposed to them, deflect from the previous path of life based on religious values in favour of the worldview devoid of them. Secularization implies processes of institutional marginalization of religion in the aspects of collective life, its privatization, which transforms into the laicization of mentality. ${ }^{4}$ However, simultaneously the reverse process called deprivatization is occurring, which is the return of the religious doctrine, the world of norms and institutional forms into the individual and social spectrum. ${ }^{5}$ In the Catholic Church this process is called evangelization or new evangelization. Therefore, in both cases we are talking about the processes connected with education, shaping models and attitudes.

\section{Motivation for choosing this subject}

I take interest in our southern neighbour, as well as many Poles do, due to the territorial vicinity of both countries. Czechs are our not very open kinsmen, but they are linguistically and culturally close. They are impressive by their pragmatism and greater lucidity of their administrative system. Czechs, referring to quotation of the Czechs' aficionado Mariusz Szczygiel, "are the part of our personality that we do not have (...)". He continues with the following statement: "We adore Czechs, because they are the nation of very different flaws from ours". Polish writer Tomasz Zubiński says that: "Czech Republic appears to us as the magical and exotic sphere, however apparently familiar as it is fairly close, but still far away and with the fairy aura". ${ }^{7}$ He refers to Czechs as the nation of optimistic pragmatists, fabulously adapting themselves to the new circumstances, caring for their national interest, realists keeping both feet on the ground, who distance themselves from cults, authorities and leaders. ${ }^{8}$ This can suffice to take interest in the Church in the Czech Republic as an important part of social life.

\footnotetext{
Ibidem, 30.

Ibidem, 30 .

Ibidem, 32 .

Ibidem, 33.

Szczygieł, M. (2009). Zrób sobie raj. Wołowiec: Wydawnictwo Czarne, 10-11.

7 Zubiński, T. (2012). Czechy egzotyczne. Toruń: Adam Marszałek, 3.

8 Ibidem, 7.
} 
The place of Church in the Czech Republic is the matter of importance. For Poles, who in the majority are Catholics, Czech's reality is often completely different, incomprehensible. Church and its members constitute the social minority. It does not consist in the simple comparison of the church attendance or worldview declaration, which can be elusive. Baptism recorded in the statistics, declared religiousness or church attendance does not have to indicate the real religious involvement. It can be, to a great degree, a usual form of staying within the frames of tradition. Nevertheless, this phenomenon occurring in the Czech society, its specificity and originality in approaching the matters of denomination and Church is fascinating.

One of the most well-known Czech clergymen, Tomáš Halík in his book: Patience for God. Faith encounters atheism, which is advertised as the best theological book in Europe, mentions: "I most clearly recall the moment, when as an 18 year old romantic, who started to read the Holy Bible (back then I had no one, who would tell me that it is unwise to read the Holy Bible as a novel, from the first to last page), I went on a pilgrimage to a damaged church with a dilapidated roof, a lot of which were on the borders of Czech Republic - to make sure whether I still believe in God or not. Indeed, this half-decrepit church, completely devoid of paintings was a reflection of the Church of those times in our country. However, this church lacking even the altar, was the place, where God could speak to the man in search of him." In connection with this quotation, I would like to use a reference to one of my experiences. During one of my weekend excursions in the neighbourhood of the beautiful cross-border village Deštné, I came across a damaged religious building that was recently reclaimed by the Czech Church. The community managed to cover it with roof tiles, which they considered a success. Having myself been accustomed to the dapper churches, I had the opportunity to participate in the liturgy in the dilapidating one, covered with a new roof, having at the disposal a simple altar from fieldstones. Standing in this old church, devoid of plaster, floor and almost any decorations, I was moved by the simplicity of the scenery and enthusiasm of the small group of Christians gathering there.

Few years ago, I prepared an analysis of the documentary of the Polish-Czech co-production entitled: "A mixed couple", for one of the Polish-Czech meetings. It was devoted to four Polish-Czech families living on the borders of these two countries. One of the film's heroes, who was a member of the Czechoslovak Church, criticized the Polish Church. He spoke of it as rather scathing and hardly acceptable for him. I did not fully comprehend his opinion, but it encouraged reflection on some discrepancies in approaching the sphere of religiousness by Czechs and Poles.

$9 \quad$ Halík, T. (2011). Cierpliwość wobec Boga. Spotkanie wiary z niewiarą. Kraków: Wydawnictwo WAM, 55-56. 
I have asked myself a series of questions: What are the sources of knowledge regarding the Czech Church? What do we, Poles, know about it? What do we know about religiousness of our neighbours? Do we know what factors contributed to creation of certain social attitudes of Czechs towards the Church and religiousness? What is the cause of distinct approach towards religious cult in Czech and Poland?

\section{Sources}

The way the Church functions in the Czech Republic and what are characteristics of religiousness of the contemporary Czechs is extremely interesting for me as well. Texts used for the research are mainly academic papers and fiction (books and articles from the newspapers) published in Poland. I used one of Tomáš Halík's publications translated to Polish. Papers concerning the issues of the Czech Church and religiousness were predominantly written by sociologists ${ }^{10}$ and Polish priests working in the Czech Republic as yet. The most influential works were created by the Polish Order of Preachers. Piotr Krzysztofiak is an author of the book Aksamitna rewolucja. ${ }^{11}$ It was dedicated to the analysis and reception of the documentary, edition of which was commissioned by the Czech Episcopate entitled: Peace and Goodness. The letter dedicated to the social matters in the Czech Republic for public discussion. It stirred a vivid public discussion in the society of our southern neighbours. By contrast, Hieronim Kaczmarek published the monumental piece of work depicting the relationships between the Church and Czech Republic from XVII century up to the contemporary times. ${ }^{12}$

Elżbieta Pałka-Szyszłak reflecting upon the meaning of the Church and religion in Czechs' lives narrows it down to the three aspects: historical, social and connected with the internal situation of Church and religious community. ${ }^{13}$ In the following part, I will primarily refer to the first two aspects.

10 Budniak, J. - Kasperek, A. (Eds.) (2001). Oblicza religijności. Polska - Czechy - Słowacja. Katowice: PAN, Studio NOA; Dębicki. M. - Makaro J. (Eds.) (1991). Sąsiedztwa III RP Czechy. Zagadnienia społeczne. Wrocław: Wydawnictwo GAJT.

11 Krzysztofiak, P. (2016). Aksamitna rewolucja. Przemiany w Czechach po aksamitnej rewolucji $z$ chrześcijańskiej perspektywy. Poznań: W Drodze.

12 Kaczmarek, H. (2016). Czechy. Kościół i państwo. Kraków: Wydawnictwo WAM.

13 Pałka-Szyszlak, E. (2001). Kościół i religia w życiu Czechów. In J. Budniak, A. Kasperek (Eds.), Oblicza religijności. Polska - Czechy - Słowacja. Katowice: PAN, Studio NOA, 127-134. 


\section{Historical conditioning of the attitude towards the Church and religious perspective}

Church in Poland is culturally and educationally embedded in the traditional institution characterized by the great continuity. It is associated with freedom in the social consciousness. The history of the Czech Church is completely different. Czechs adopted Christianity several decades before Poland. At the foundation of aversion of Czechs towards the Catholic Church lay some historical issues, lack of acceptance of Jan Hus, who was deceitfully brought to the Council of Constance and burnt alive. He created a program of advocacy of Czech interests, Czech language, introducing it to the Church. His movement that was formed during Reformation greatly impacted generations of enlightened Bohemians. In XVII century failure of the Protestant gentry (White Mountain 1620) defeated and obliterated by Catholic Habsburgs destroyed not only Hussitism, but the whole social class. Gentry either died away or collaborated with the authorities and converted to Catholicism. The Bohemian lines were substituted by the Austrian families. Jesuits transformed it again into the Catholic country, but the Catholicism was strongly identified with the occupant. The old faith was restored not by the "zealousness of the missionaries, fervent care of the Jesuits or beauty of the culture of the Baroque, but unfortunately by violence, repression and ruthless banishment of those, who did join them in their faith." 14 Two Bohemian upsurges caused a great upheaval in the major part of the Europe. Both Hussitism, as well as the set-up of the antagonism between the Catholics and heathens in the XVII century caused the extensive perturbations in many European countries. ${ }^{15}$ AustroHungarian Empire imposed Catholicism on the protestant Czechs. It was a specific alliance of the throne with the altar. The Church was perceived as a hostile factor, which did not foster the national revival. After the formation of Czechoslovakia in 1918, the Church authorities in Rome rejected the postulates of the revision of Jan Hus' trial, the introduction of the Czech language to the liturgy and the abolishment of celibacy advocated by 1000 priests. In consequence, the Czechoslovak Church was established and two decades characterized by both antiCatholicism and anticlericalism followed. ${ }^{16}$ The formation of the Czech Republic indicated the nullification of Counter Reformation and re-catholicisation done by the Habsburgs. ${ }^{17}$

After the World War II the Church was cracked down, bishops were detained and sentenced in fake trials, the monasteries were closed down and monks were

14 Halík, T. (2011). Op. cit., 73.

15 Dębicki, J. (1991). Op. cit., 27-29.

16 Szczygiel, M. (2009). Op. cit., 141-146.

17 Decreux, M. E. (2000). Tożsamość Czechów - pomiędzy katolicyzmem a protestantyzmem. In J. Kłoczowski (Ed.), Historia Europy Środkowo-Wschodniej, Vol. 2. Lublin: Instytut Europy Środkowo-Wschodniej, 189. 
placed in the labour camps. The subordinated priests were turned into state officials, who were forced to oblige under surveillance, rendering priesthood a peripheral activity. In response to this situation, the clandestine, independent church was formed, consisting of tens of thousands of people. ${ }^{18}$ Communist repressions were targeted at the clergy, devoiding churches of financial potential and as a result influencing people in order to turn them against the Church. ${ }^{19}$ Forced and top-bottom controlled secularization encompassing the Czech Republic, similarly to the situation in GDR, induced the deep transformations in the attitudes and behaviours of the citizens. In the wake of these modifications, the fall of communism did not lead to a vehement return to faith or the Church. ${ }^{20}$ Additionally, in the social consciousness of Czech people the Catholic Church was identified with the occupant since the Reformation, however, this statement is certainly a simplification. Only until the Velvet Revolution, the religious freedom was brought along with it. Just after it happened, the society started to relate to the Church with esteem and respect, identifying it as the authority connected with democratic opposition. With time this social affection diminished. Its reputation was overshadowed by the trials regarding repossessions of Church financial assets.

The history of the Czechs can be placed over the course of conflict between the Slavic and German nations and on the other hand, tension between Catholicism and Protestantism. ${ }^{21}$

\section{The social dimension of the religiousness of contemporary Czechs}

First of all, contemporarily there is not one, primary church in the Czech Republic as there are numerous churches and religious associations functioning there. Since Jan Hus times, the Reformation Church has been the most strongly rooted one. There are several churches in the contemporary Czech Republic. The most numerously represented ones are presented in the table 1 below:

18 Szczygieł, M. (2009). Op. cit., 147-149.

19 Kania, T. (2001). Specyfika i główne tendencje prześladowania Kościoła katolickiego w Czechosłowacji w okresie komunizmu (z wyróżnieniem terenów pogranicza kulturowego Śląska Cieszyńskiego). In J. Budniak, A. Kasperek (Eds.), Oblicza religijności. Polska - Czechy - Słowacja, Katowice: PAN, Studio NOA, 159-160.

20 Świątkiewicz, W. Op. cit., 48.

21 Decreux, M. E. Op. cit., 187. 
Table 1. Denominational structure of the Czech society in 2011.

\begin{tabular}{|r|l|r|c|}
\hline Lp. & Denomination & $\begin{array}{c}\text { Number } \\
\text { of members }\end{array}$ & $\%$ \\
\hline 1. & The Latin Church & 1082000 & 10.4 \\
\hline 2. & Evangelical Church of Czech Brethren & 51858 & 0.5 \\
\hline 3. & Czechoslovak Hussite Church & 39229 & 0.4 \\
\hline 4. & Christian Orthodox Church & 13069 & 0.1 \\
\hline 5. & Jehovah's Witnesses & 20533 & 0.2 \\
\hline 6. & $\begin{array}{l}\text { Silesian Evangelical Church of the } \\
\text { Augsburg Confession }\end{array}$ & 0.1 \\
\hline
\end{tabular}

Source: Náboženská víra obyvatel podle výsledků sčítání lidu. Praha: ČSÚ, 2014, 5.

The phenomenon of the Czech church consists in the fact that just after the outbreak of the Velvet Revolution and the fall of Communism, the statistical number of people declaring religious involvement had increased. The high statistical numbers are depicted in the table above. There was a subsequent decrease in the number of the worshippers, which was explained not as diversion from religiousness, but much more as a realization of what religious involvement means. After a short-lived period of few years, where the Church was idealized as the main authority opposing the communist regime, it was demythologized. New churches and religious communities emerged leading to the 'privatization' of religion. The process of separation of the religiousness from the Church was enhanced again.

The alternation of the model of religiousness in the Czech Republic was influenced as well by the demographical processes. Young people are growing and shaping up regardless of the Church. ${ }^{22}$ Elżbieta Pałka-Szyszlak pinpoints that especially the Catholic Church did not use the opportunity, which he had after the reclamation of independence. Among the mistakes made, the appointment of the wrong people at the posts at church, purposive pursuance to restitute the financial assets, lack of settlement of the past collaboration of priests with the communist authorities were pointed out. Other churches in Czech Republic were in the crisis as well, which consisted in the internal breakage and financial and social scandals. ${ }^{23}$

Czechs and the authors of books regarding Czechs refer to it as the most atheistic country in the world. In the source literature, many voices speaking of the Czech Republic as a secularized country are cited. T. Halík said that "the country

22 Pałka-Szyszlak, E. Op. cit., 132.

23 Ibidem, 132-135. 
I was born in and where I live is considered the most atheistic country in the whole world". ${ }^{24}$ The author wonders whether faith can be measured solely by the number of people, who admit that they belong to this or different church, attend the church services and give a positive answer when questioned in the public poll whether they consider themselves believers and whether this automatically renders the rest of the society atheists. ${ }^{25}$ In contrast, Czechs manifest "the fearful piety" as called by Tomás Halík. It is characterized by the secularization, moderation, discretion, separation from the manifestations of the public piousness in church and keeping distance from the church forms of Christianity. ${ }^{26}$ The president of the Seminary in Prague, previously working in one of the parishes in the Czech Republic, the Polish priest Artur Matuszek answers the question whether the Czech Republic is the most secularized country in Europe - yes, when atheism is understood through church attendance only. Apart from the aspect of culturally and historically conditioned "anticlericalism", Czechs are typified by the "spiritual and religious sensitivity" ${ }^{27}$ They embody opposition towards any official and institutional forms of religion, resistance more pertaining to the "anticlericalism" than atheism, which frequently manifests itself by the peculiar mixture of affection and antipathy (sometimes born out of disappointed love) ${ }^{28}$ According to E. PałkaSzyszlak "it does not mean that Czechs are an atheist society. They are as equally indifferent to atheism as to religious matters. For the majority of them, religious values and matters do not constitute the stable, vital part of their daily life, yet they do not exclude the existence of ultimate matters. ${ }^{29}$ Certain fragmentary illustration of the religiousness of Czechs is contrasted with the neighbouring nations' religious involvement in the table 2 .

Halík, T. Op. cit., 73.

Ibidem, 72 .

Ibidem, 72 .

Polski ksiądz w Czechach. Rozmowa z ks. Arturem Matuszkiem. Życie Duchowe, 2012, nr 72, 137.

Halík, T. Op. cit., 75.

Pałka-Szyszlak, E. Op. cit., 136. 
Table 2. Czechs' religious involvement contrasted with the societies of the Visegrad Group.

\begin{tabular}{|c|l|c|c|c|c|}
\hline Lp. & $\begin{array}{l}\text { Frequency of attending } \\
\text { church services }\end{array}$ & Rybnik & Szeged & Nitra & Hradec \\
\hline 1. & I attend church regularly & 69.8 & 11.1 & 17.8 & 2.5 \\
\hline 2. & $\begin{array}{l}\text { I attend church from time to } \\
\text { time }\end{array}$ & 24.0 & 49.1 & 22.3 & 2.7 \\
\hline 3. & I attend church on holidays & - & - & 17.4 & 3.8 \\
\hline 4. & I attend church rarely & - & - & 6.1 & - \\
\hline 5. & I do not practice & 5.6 & 39.8 & 19.4 & 89.3 \\
\hline 6. & Other answers & - & - & - & 1.7 \\
\hline 7. & Lack of answer & - & - & 17 & - \\
\hline
\end{tabular}

Source: Świątkiewicz, W. (2001). Relikt przeszłości czy żywa codzienność? Refleksje wokół badań nad religijnością współczesną w krajach wyszehradzkich. In J. Budniak, A. Kasperek (Eds.), Oblicza religijności. Polska - Czechy - Słowacja. Katowice: PAN, Studio NOA, 38.

In view of the results of the research juxtaposed in the table above conducted by the multidisciplinary team, "from amongst four societies in the sociological sense, Poles are the most religious and massively declare their adherence to the Latin Church. It is reflected in the sociological studies, opinion polls and church statistics. Nevertheless, 'conclusions regarding Polish religiousness or its quality"'30 cannot be drawn. Yet it is beyond doubt that the results relating to the religious practices place our south neighbours at the last position from the studied countries. Taking into perspective indicators of the quality, it is apparent that the laicization of the Czech society is progressing. Studies carried out over the course of years 1992-2006, indicate that solely $10 \%$ of the respondents attend the church service once a month. In contrast $50-60 \%$ of the respondents do not attend church at all. ${ }^{31}$ It is worth pinpointing that there is an increase in the number of the atheists, drop in the number of people receiving the sacraments and scarce church services attendance. These factors can be acknowledged as the withdrawal from the traditional religiousness in Czechs. On the other hand, the interest in the forms of religiousness that do not pertain to Church is observed (faith in afterlife, heaven, reincarnation, interference of the dead ones into the life). ${ }^{32}$

30 Świątkiewicz, W. Op. cit., 38.

31 Ibidem, 38.

32 Pałka-Szyszlak, E. Op. cit., 123. 
Czech Catholics wonder about the future of the Church and paths of societal development in the religious sphere. Hieronim Kaczmarek, who carefully follows the debate with regard to the future of Church in the Czech Republic specifies a few essential directions for research set up by the people related to Church. $\mathrm{He}$ emphasizes Tomás Halík's opinion on the necessity for the self-determination of Church and ability to engage into the dialogue with the whole society. Aleš Opatrný puts an accent on the essentiality to recourse to the tradition and social sciences including pluralism and individualism of the Czech society. He refers to the Pavel Ambros' point of view, who states that Church will be attractive for the society, if it can create a different set of relations occurring in the other institutions, which focus more on faith, self-development of an individual and bringing unity into the community, simultaneously relinquishing bureaucracy. ${ }^{33}$

\section{Conclusion}

Considering the Czech Church and the religiousness of our southern neighbours, we need to take into account historical differences that underlie experiences of Czechs and Poles. Perspective of the Catholic Church was and is definitely distinct as it was mightily associated with occupants, since the Reformation through the XVII century and thereafter. Czechs are distinguished by the high level of laicization. Their religiousness takes discrete, private forms. There is a high level of distrust towards the institutional church as well as the propensity to criticize it. Though, depiction of Czechs as atheists is not entirely true. It is worth bearing in mind that the Czech Republic is the place of the strong influence of two complementary Christian traditions, which are mutually confronting and completing - Protestantism and Catholicism.

33 Kaczmarek, H. Op. cit., 308-310. 